UDK: 821.163.42.02"18“

Pregledni članak

Primljen 16. IV. 2018.

MARIJAN ŠABIĆ

Hrvatski institut za povijest - Podružnica za povijest Slavonije,

Srijema i Baranje

marijansabic@yahoo.co.uk

\title{
PROGRAMI HRVATSKOGA KNJIŽEVNOG ROMANTIZMA (IZMEĐU NACIONALNOGA ROMANTIZMA I ROMANTIČNOGA NACIONALIZMA)
}

\section{Sažetak*}

Autor u članku daje pregled programa hrvatskoga književnog predromantizma i romantizma i s njima preklapajućega narodnog preporoda i ilirizma te pokazuje kako su se u programskim tekstovima, u okolnostima mađarsko-hrvatskih napetosti i neoapsolutizma, izmjenjivale tendencije nacionalnoga romantizma i romantičnoga nacionalizma, kako ih je u europskim okvirima definirao Joep Leerssen.

Ključne riječi: hrvatski romantizam; hrvatska književnost; romantični nacionalizam; kulturni programi; politički programi

Shvatimo li književnopovijesne epohe kao korisne elaboracijske i opisivačke alate kojima nastojimo uvesti određenu razinu preglednosti u skupove književnih tekstova, lakše će nam biti shvatiti i osnovne elaboracijske probleme s romantizmom, a to su: nije se u svim europskim

\footnotetext{
* Ovaj je rad sufinancirala Hrvatska zaklada za znanost projektom IP-2018-01-2539.
} 
književnostima javio istodobno, nije se pojavio iz istih pobuda i nije se svugdje istim načinom manifestirao. Književni je romantizam, prema Dubravku Jelčiću, prije svega bio vezan uz ideju slobode, kod zapadnih europskih naroda više na umjetničkome, a u Hrvata, Slovaka, Čeha, Slovenaca i Poljaka na preporodno-političkome planu (Jelčić, 2002: 13). Hrvatski je književni romantizam kao i kod većine slavenskih srednjoeuropskih naroda bio praćen narodnim preporodom kao pokretom za osamostaljenje naroda u različitim aspektima - od jezičnoga i općekulturnoga do političkoga u najširem smislu riječi. Preporodni je pokret bio usmjeren na pokazivanje i dokazivanje određenih kvaliteta naroda kao jamaca njegove samostalnosti i neovisnosti te kulturne, jezične, književne, državnopravne tradicije na njihovo utvrđivanje i aktualizaciju.

I u hrvatskome su se preporodu ispreplitale kulturna i politička komponenta. Književne je povjesničare često intrigirao problem terminološkoga, kronološkoga i drugoga razgraničenja te suodnosa narodnoga preporoda i književnoga romantizma kod spomenutih zapadnoslavenskih i južnoslavenskih naroda. Roman Jakobson je svojevremeno pisao o dva antipodska lica romantizma unutar jednoga češkog naroda, o europskome i specifično nacionalnome romantizmu, no isti su književnici u češkoj, pa i u hrvatskoj književnosti, pisali i nacionalno-preporodne i književno-romantičarske tekstove. U predmetnome je razdoblju gotovo sve nacionalno bilo beletrizirano, i to na romantičan način, a beletristika hrvatskoga romantizma imala je višestruku nacionalno-integracijsku ulogu. Vinko Brešić naglašava razliku između preporoda i ilirskoga pokreta s jedne te romantizma i ilirizma s druge strane. Prva dva pojma pripadaju društvenoj povijesti, s tim da je ilirski pokret preporodna faza (1836. - 1843), dok druga dva pojma pripadaju kulturnoj/književnoj povijesti, s tim da je ilirizam isto što i hrvatski romantizam, tj. hrvatska inačica europskoga romantizma (Brešić, 1994). Dubravko Jelčić pak odbija govoriti o romantizmu u hrvatskoj književnosti jer smatra da sintagma „hrvatski književni romantizam“ bolje ističe osobine ovoga razdoblja hrvatske književnosti. Nacionalna romantika preporodnoga pokreta, tvrdi Dubravko Jelčić, dala je glavni sadržaj i bitna obilježja hrvatskomu književnom romantizmu, naročito u njegovoj prvoj fazi. Otuda, veli, 
proizlaze sve razlike između njega i romantizma u zapadnoeuropskim književnostima: utilitarnost i didaktika, polet i rodoljublje, optimizam i vedrina itd. (Jelčić, 2002: 54). Za vremensko je situiranje hrvatskoga romantizma koji se isprepliće s narodnim preporodom vrlo uporabljiv i pojam nacionalni romantizam, kako ga je definirao Joep Leerssen. U grubim crtama pojam National Romanticism jest umjetnički, poetski i odnosi se na kulturu u širem smislu riječi, koja je inspirirana rodoljubljem, domoljubljem, nacionalizmom itd., dok bi Romantic Nationalism bio politička strana iste medalje koja će uporabiti, instrumentalizirati umjetnost, ali i bilo koji drugi oblik kulture, u nacionalno-integracijske svrhe. Čini nam se da šest primjera programskih tekstova pretežno književnoestetske naravi, koje je Miroslav Šicel uvrstio u poglavlje „Od hrvatskog književnog preporoda do realizma“ svoga zbornika Programi i manifesti u hrvatskoj književnosti (Šicel, 1972: 15-74), ne mogu biti dovoljno ilustrativni za osvjetljavanje romantičnoga nacionalizma (naročito njegovih izrazito političkih aspekata) u predmetnome razdoblju, pa će se naš izbor programskih tekstova nešto razlikovati od Šicelova.

Prema Leerssenu, putanja je romantičnoga nacionalizma u europskoj povijesti obilježena: 1. naglim usponom nakon 180o., 2. postupnim bujanjem od 1820. do 1870. (Leerssen, 2014: 5-6). Otprilike u te vremenske okvire, od 1820. do 1870., i različiti hrvatski autori smještaju razdoblje od početaka hrvatskoga preporoda do, kako piše Jelčić, ranoga predrealizma ili, prema Slavku Ježiću - do kraja hrvatskoga romantizma i Hrvatsko-ugarske nagodbe 1868. (Ježić, 1993: 219-245). Miroslav Šicel, izdvajajući posebno ilirizam i preporod, razdoblje romantizma i predrealizma proteže od kraja apsolutizma do Šenoine smrti (1860. - 1881.) (Šicel, 2004), a u svoju je antologiju Programski spisi hrvatskog narodnog preporoda uvrstio i tekst Adolfa Vebera Tkalčevića Najnoviji pojavi našega pjesničtva iz 1866. Nas će ovdje zanimati programi koji su uglavnom bili artikulirani u programskim tekstovima, a orijentirat ćemo se na razdoblje od prvih programskih tekstova (1813.) do 1860.

Osim što je jasno da su programski tekstovi kao manifesti djelovali na motivaciju, poetiku i jezik književnosti pojedinih autora, valja imati na umu da je u 19. stoljeću književnost imala puno veće značenje nego 
danas, tj. da su refleksije književnosti kao sustava imale odjeka na cijelu društvenu elitu pismenih ljudi, koji su tada, iz današnje perspektive možemo to mirno reći, ujedinjavali, organizirali i vodili hrvatski narod. Ti su tekstovi, osim o književnosti, progovarali i o cijelome aktualnom hrvatskom kulturnom i političkom trenutku, koji je u prvoj polovici 19. stoljeća obilježilo:

1) obnavljanje svijesti o jedinstvu povijesnoga državnog prostora i politička nastojanja na njegovu ponovnom ujedinjenju

2) oblikovanje svijesti o hrvatskome narodnom jedinstvu Slavonaca, Dalmatinaca i „Horvata“, u čemu je vrlo važnu ulogu imala i činjenica da su imali zajedničku krunu

3) uspostavljanje jezičnoga zajedništva i rad na zajedničkome standardnom jeziku

4) unaprjeđivanje hrvatske književnosti, kako s jezičnoga aspekta tako i s aspekta izgradnje hrvatskoga književnog kanona i praćenja suvremenih europskih književnih gibanja

5) utemeljenje institucija važnih za narodni razvitak, kao što su političke stranke, političke novine, književni časopis u najširem smislu riječi, tiskare, čitaonice, narodno kazalište, Matica ilirska, gospodarsko društvo, narodni muzej itd.

Nositelji tih težnji bili su hrvatski intelektualci i nacionalno-integracijski poduzetnici, uglavnom predstavnici obrazovanoga građanstva koje u prvoj polovici 19. stoljeća dobiva uzlet i proširuju mu se politička prava, sve do sudjelovanja u Hrvatskome saboru 1848. Među nositeljima hrvatskih preporodnih težnji bio je i dio plemstva i visokoga, pa i najvišega svećenstva. Zagrebački biskup Maksimilijan Vrhovec uputio je 1813. svećenicima svoje biskupije Poziv na sve duhovne pastire svoje biskupije. Izvorno je taj poziv upućen na latinskome, no ilircima je bio inspirativan, pa je 1837. uz latinski izvornik u Danici objavljen i njegov hrvatski prijevod. Zašto je ovaj tekst važan? U njemu je biskup pozvao svećenike da mu jave o svim starim knjigama koje se nalaze po njihovim župama, a koje su pisane narodnim jezikom, te da zapisuju poslovice, pjesme i, općenito, riječi za koje smatraju „da čistoći i diki ilirskoga 
jezika pruditi mogu, dodajući svakoj rěči njezinu silu, potrěbovanje, značenje i raztumačenje“. Zapravo, riječ je o prikupljanju građe za korpus budućega književnog hrvatskoga jezika ili, kako ga Vrhovec naziva, ilirskoga jezika. Ova biskupova okružnica imala je sva obilježja kratkoga programatskog teksta: uvod, u kojem se navode najvažnija djela u horvatskome i slavonskome jeziku, u glavnome se dijelu obrazlaže potreba za izgradnjom zajedničkoga jezika, te se na kraju poziva svećenike na angažman jer se u Beču osniva „družtvo muževah, koji narěčja ilirskoga jezika iz tmine izkopati i obdělati nastoje“. Iz Poziva Maksimilijana Vrhovca može se iščitati kako hrvatski i slavonski smatra narječjima jednoga jezika koji treba obnoviti i standardizirati, smatra da se pri tome treba oslanjati na postojeću književnu i jezikoslovnu tradiciju i, što je vrlo važno kao znak da ovaj tekst već pripada nacionalnomu romantiz$\mathrm{mu}$ - kako ga vidi Leerssen, da vokabular za standardni jezik treba crpiti i iz usmene predaje hrvatskoga i slavonskoga puka kao etnički definirana naroda. A što je inače usmena pučka književnost značila za srednjoeuropski, bilo slavenski bilo germanski romantizam, ovdje ne trebamo posebno isticati.

Knjiga Temelj zitne trgovine iz 1796. jest bila gospodarske tematike, ali je u njezinu predgovoru autor Josip Šipuš, potaknut sasvim praktičnim razlozima, također postavio problem zajedničkoga jezika uspoređujući hrvatske dijalekte s različitim njemačkim govorima. Osim toga, istaknuo je i problem koji će dugo mučiti hrvatsku filologiju, a to je problem nedostatne znanstvene terminologije, nedostatka riječi kojima bi u svojoj knjizi uspio obuhvatiti sve što je želio reći. Proći će više od pola stoljeća od Šipuševa predgovora dok hrvatski jezik 1847. ne postane uredovni u Hrvatskome saboru, do tada je to bio latinski. Upravo se toj uredovnoj upotrebi latinskoga jezika suprotstavio Antun Mihanović u svojoj brošuri Reč domovini od hasnovitosti pisanja vu domorodnem je$z i k u$ (1815.) Veći dio ove brošure prerada je gotovo istoimenoga spisa talijanskoga racionalističkog književnika Francesca Algarottija iz sredine 18. stoljeća. Izvorni je završni dio u kojem Mihanović zanosom romantičarskoga pjesnika, što je prije svega i bio, brani korisnost uporabe hrvatskoga jezika za opće interese domovine. Mihanović ističe potrebu rada 
na jeziku, i to tako da oni koji posjeduju znanja u tuđim jezicima - ta znanja pokušaju prenijeti u narodni govor, kao što je svećenstvo radilo s vjerskim naukom i propisima. Za uporabu narodnoga, domorodnog jezika trebalo je pronaći dobre razloge jer je u odnosu na, primjerice, njemački i latinski bio prepun nedostataka, jednostavno - bio je „težak za rukovanje“. Iz takvih se nastojanja, naročito kod Čeha i Slovaka, razvio cijeli polemički žanr obrane narodnoga jezika, koja je obično išla zajedno s obranom naroda koji je taj jezik koristio. Tomu je žanru pripadao upravo ovaj Mihanovićev spis i postao je jedan od najutjecajnijih u razdoblju hrvatskoga preporoda, za razliku od njegova proglasa Znanostih i narodnoga jezika prijateljem (1818.), objavljena u Padovi, kojim je pokušao zainteresirati javnost za objavljivanje Gundulićeva spjeva Osman.

Vidimo da je Ljudevit Gaj imao već na čemu graditi kada je u jedinstvenu pravopisu i književnome jeziku predložio kulturni program sjedinjenja svih Hrvata, a s njima u istome jeziku i Slovenaca. Riječ je, dakako, o njegovu djelu Kratka osnova horvatsko-slavenskoga pravopisanja (1830.) na 27 stranica. Paralelno hrvatskim i njemačkim obraća se izrijekom „domorodcima Horvatima“, poziva ih na njegovanje narodnoga jezika i izbacivanje stranih utjecaja iz hrvatskoga pravopisa, a skupa s njima i, kako je on smatrao, viška znakova kako bi se pisalo jedno slovo za jedan glas. Njegovi su ciljevi jasnoća i jednostavnost kako bi se hrvatska knjiga približila svim Slavenima, da se može čitati u i među Česima i Poljacima. Ovdje Gaj zastupa tada rašireno shvaćanje jednoga velikog slavenskog jezika koji se grana u četiri glavna narječja: rusko, češko, poljsko i ilirsko. Premda je bila riječ o prijedlogu pravopisne reforme hrvatskoga jezika, Kratka osnova bila je upravo to - kratka osnova, ne nekakav cjelovitiji pravopisni sustav, inače o njoj ne bismo govorili kao o programskome tekstu. U njoj je Gaj govorio o temeljima pravopisa: samoglasnik $i$ dosljedno pisati grafemom $i$ umjesto $y$, za 7 nepčanih suglasnika uvesti nova slova dodavanjem dijakritike, ne kvačice nego tilde itd. Danas je jasno da njegovi konkretni prijedlozi nisu imali naročita uspjeha u početnoj primjeni - prije svega što je za temelj standardnoga jezika predložio kajkavsko narječje, ali ni tiskare nisu imale nova slova (pa i Gajeva je tiskara započela s radom osam godina kasnije). Gaj je bez 
sumnje bio ponajbolji operativac među preporoditeljima. Za pravopisnu reformu više su zasluga imale njegove Danica i Novine nego Kratka osnova, međutim - povijesna važnost ove Gajeve brošurice bila je ta da je objavljena u pravo vrijeme i na pravome mjestu, u vrijeme kada su se među najvatrenijim mladim zagrebačkim ilircima aktualizirala načela koja smo vidjeli kod Mihanovića i kod Vrhovca, pa čak i kod Šipoša četrdesetak godina prije.

O značenju hrvatskih književnih časopisa u 19. stoljeću, pa i Gajeve Danice, ovdje nećemo posebno govoriti jer je to prevelika tema, a i 2015. je okončan znanstveni projekt o hrvatskim književnim časopisima, koji je na Filozofskome fakultetu u Zagrebu vodio Vinko Brešić. Upozoravamo tek na Gajeve proglase uz Narodne novine i Danicu iz 1834., 1835. i 1842., u kojima je upravo programatski izložio svrhu i važnost redovito izlazećih političkih novina i književnoga časopisa na narodnome jeziku. Sva tri ova proglasa objavio je Dubravko Jelčić u knjizi Hrvatski književni romantizam (Jelčić, 2002: 155-166).

Nakon Bečkoga kongresa kritičari Metternichova sustava počeli su propagirati ideju da teritorij neke države ne bi trebao odražavati moć monarha, nego povijesnu i suvremenu nazočnost (etnički i kulturno definirana) naroda na tome teritoriju (Leerssen, 2014: 10). Težnje za narodnosnim samoodređenjem bile su u prvoj polovici 19. stoljeća opći trend u Austrijskome Carstvu, a u traženju građanskih i narodnih sloboda prednjačili su Mađari. U takvim okolnostima razvija se hrvatsko-mađarski sukob, temeljen na različitim shvaćanjima odnosa između Ugarske i Hrvatske. Ove su napetosti uvelike odredile smjer političkih i kulturnih programa hrvatskoga romantizma i izravan su povod nastanku programskoga spisa Disertacija iliti razgovor, kojeg je napisao grof Janko Drašković (1832.). Riječ je o, prema mnogima, najpotpunijem i najvažnijem programskom tekstu hrvatskoga preporoda u kojem Drašković daje odgovore na gotovo sva važnija pitanja pred kojima se hrvatski narod našao u tadašnjoj situaciji. Spis je oblikovao kao upute iskusna domorodca (Drašković je tada imao 62 godine) hrvatskim zastupnicima za što se sve trebaju zalagati u svome političkom djelovanju, a to je: sjedinjenje hrvatskih pokrajina, ravnopravni odnosi s Ugarskom, 
politička samostalnost, tj. reinstalacija posebne vlade za Hrvatsku i obnova banske vlasti, uvođenje službenoga hrvatskog jezika, jačanje gospodarstva, razvoj školstva, vjerska ravnopravnost i umjerene reforme u društvu na korist nižih slojeva itd. Zanimljiv je uvod u kojem obrazlaže da se odlučio pisati štokavskim dijalektom jer njim, kako je potkrijepio i tabelama u prilogu, govori većina "Slavo-Hrvata“, a kako je bio rođeni Zagrepčanin, odlučio ga je naučiti. Drugi razlog zbog kojega se odlučio za ovaj jezik jest to što su njim, kako kaže, pisane sve naše starije knjige, tiskane od Splita, Mletaka i Dubrovnika do Zagreba i Požege.

Hrvatsko-mađarski odnosi su tijekom tridesetih godina 19. stoljeća postali toliko napeti da je isti grof Drašković u prosincu 1839. predložio u Skupštini Zagrebačke županije da se Hrvatska odcijepi od Ugarske i zatraži od kralja posebnu vladu. Otprilike tu negdje dolazi, prema Slavku Ježiću, i do početka kraja poetične i fantastične periode romantičnoga nacionalizma u Hrvatskoj, a težište preporodnih nastojanja prelazi s kulturnoga na politički plan (Ježić, 1993: 203). Naročito to dolazi do izražaja nakon osnivanja Hrvatsko-ugarske stranke 1841., na čelu s braćom Rauch i turopoljskim županom Josipovićem, koja je bila izravno suprotstavljena hrvatskim preporoditeljima okupljenima u Ilirsku stranku, odnosno nakon što je u siječnju 1843. zabranjeno ilirsko ime u Narodnu stranku. U okolnostima sukoba ovih dviju stranaka nastaje i najpopularniji programski spis koji je objavljen u drugoj polovici 1842., a niti pola godine poslije već je uvršten na popis zabranjenih knjiga. Bio je to Mali katekizam za velike ljude Dragutina Rakovca. Kao što crkveni katekizam u obliku pitanja i odgovora izlaže načela crkvenoga nauka, tako je Rakovčev spis u obliku pitanja i odgovora izlagao temelje tadašnjega preporodnog političkog programa. Među pitanjima se nalaze i: Otkuda to dolazi, da ona strana Hrvata ima mađarske namjere? $\mathrm{Na}$ koje pokrajine namjeravaju Mađari narodnost, jezik i načela svoja protegnuti? (I odgovara: na Hrvatsku, Slavoniju, slavonsku Granicu, Rijeku itd.), Je li u Ugarskoj potreban jedan samo poslovni jezik? (Ne u konštitucionalnoj državi.) Zašto se ne želimo zvati Hrvati nego Iliri? (Jer se Horvatska sastoji od 3 varmeđe, tj. županije, a ne mogu 3 varmeđe imati svoju književnost.) Je li narodnost i jezik svetinja svakoga naroda? 
Zašto na svom grbu imamo mladi mjesec i zvijezdu? itd. Na kraju spisa decidirano navodi:

Šta mi hoćemo?

Mi hoćemo:

1) Da imamo narodni naš jezik, kog nam je ista narav dala. Znamo mi da sa smrću narodnog jezika i narod isti umire.

2) Da imamo narodnu našu literaturu; jerbo bez narodne literature i isti jezik propasti mora.

3) Da narod naš prosvijetimo, što je jedino u narodnom jeziku moguće. Tuđi jezici kadri su samo pismene ljude prosvijetiti, ali nikada čitav narod.

4) Da neoskvrnuta sačuvamo naša municipalna prava, ona bo su temelj našega političkoga bića.

5) Da i odsad kao i dosad budemo braća Mađarâ pod konštitucijom ugarskom.

Šta mi nećemo?

Mi nećemo:

1) Da nas drugi ma koji narod kao gradivo samo smatra za povekšati broj jednoplemenika svojih.

2) Da nas drugi budu ružili, grdili, u sumnju dovodili, a mi da ne smijemo ni zinuti, i ni riječi odgovoriti. (Martinčić, 1994: II, 26).

Premještanjem javnoga djelovanja preporoditelja u politiku najviše je bio pogođen Stanko Vraz, koji je jedini među njima bio isključivo književnik, te je još 1837. napisao Odgovor braći što žele da pjevam davorije. On, Rakovac i Vukotinović su časopis Kolo, koji je trebao, kako je Vraz napisao češkomu pjesniku Erbenu, „dignuti književnost našu, približujući ju ukusu i duhu ostale braće slavenske, koja evropskoj izobraženosti bliže stoje." (Vodnik, 1993: 196-198). Kolu je prethodio skroman oglas, nije bilo gromoglasnih proglasa kojima je Gaj pratio Danicu, međutim, sama pojava Kola upozorava nas da program ne mora biti uvijek biti praćen eksplicitnim programskim tekstom. Ideja i koncept o časopisu koji će unaprjeđivati nepolitički, kulturni dio hrvatskoga javnog života, baviti se literaturom, umjetnošću i narodnim životom koliko-toliko odvojeno od dnevne politike, kao okupljalište književne i znanstvene elite naroda, u punome će svjetlu pokazati svoju korisnost za vrijeme 
neoapsolutizma. Krug oko Kola htio je osnažiti literarnu komponentu hrvatskoga preporoda i nastojao graditi nacionalni književni kanon ili bar estetske norme koje bi vodile njegovu stvaranju. U nastojanjima za literarizacijom hrvatskoga književnog korpusa Vukotinović, Vraz i Rakovac smatrali su da bi za hrvatsku kulturu i hrvatski nacionalni identitet u nastanku bilo pogubno podlijeganje domaćih pisaca utjecaju romantičarskih poetika snažnih nacionalnih, zapadnih književnosti (njemačke, francuske, engleske). Čitajući Kolo, naišli smo čak i na nagovještaje potrebe za oprezom pri kontaktu sa sličnim slavenskim narodima kao što je bio češki. To se prije svega odnosi na jezik Kola, koji slavenske tuđice, dakle rusizme, bohemizme i polonizme, izbjegava gotovo koliko i germanske. Vrazovo je nastojanje na čistoći hrvatskoga jezika, kako bi se stvorio jezični standard koji bi vodio prevladavanju regionalnih granica i stvaranju nacionalnoga identiteta, izraženo još 1836. u pismu Ivanu Mažuraniću:

G. Gaj kaže, čini mi se, na jednom městu: Danica je měrilo od napredovanja domorodstva; ja je pomnjivo i pozorno čitam i smatram da žalibože! Odviše naprěduje, razkosjem sam je nastupao i naslědivao u Krajinu i Dalmaciju no sada dreseljem i zlovoljom gledam kako stupa prěko medjaša Ilirskih - ter se prema sěvru uklanja; i ako tako plaho i uzpěšno naprěduje ćemo za několiko godinah (ako Bog dada i srěća domorodska sa nekoliko měsecah) sa čela Danice ilirske čitati uresne rěči wypřehnaut,, křepelka: i wyprzegać i przepióreczka: ćava i žonka, kakono sada čitamo, clověčestvo, otečestvo, vozduh, vozkliknuti i ostale rósizme. Ako se uklanjamo Karybdide treba li da zabašemo u Skyllu? nije-li nam nerazborita Serbljad pokazala gděno je jejzin berlog? Ja neću prestati kupiti i čitati Danice, no ima mnogih od našeg obćinstva (danično-ilirski obśčestvo) koji nerazumiv takove Ilirščine se polahko odmetnu i odvaržu opet u Slavonce, Horvate-zagorce ili Štajerce... (Šrepel, 1897: 240-241).

Dakle, iako Stanko Vraz nije napisao nekakav znamenit programatski tekst, to nikako ne znači da nije imao svoju viziju ilirskoga preporodnog programa, ali se u njemu usredotočio na književni i jezični plan koji je vidljiv iz koncepcije Kola ili barem iz njegova prva tri godišta, koja se obično nazivaju „Vrazovim Kolom“, i svakako iz Vrazovih kritičkih 
tekstova i eseja o književnome jeziku i pjesništvu kao što su O Dubrovčanima i Sud o slogu.

U studenome 1842. Ljudevit Vukotinović u Kolu objavljuje članak „Ilirizam i kroatizam“, vjerojatno kao reakciju na tvrdnje da ilirci žele osnivanje velike Ilirije, koje su dolazile iz krugova. Vukotinović kaže: „Kroatizam je život naš politički. Kroatizam je zaštita, pod kojom mi radimo. U smislu konštitucionalnom svi smo Horvati." (Vukotinović, 1842: 110). Ilirizam mu u političkome smislu ne znači ništa, prvenstveno je književnojezični pojam, ali i rodoslovni, jer Ilire smatra granom velikoga slavenskog stabla. Čitajući Vukotinovićev članak, postaje jasnije i Brešićevo inzistiranje na izjednačavanju ilirizma i hrvatskoga književnog romantizma. Svoje je ideje o uvjetima za razvoj narodne književnosti Vukotinović iznio također u Kolu 1843., u članku „Tri stvari knjižestva: ukus, sloga, kritika“.

Na prijelazu iz 1842. u 1843. u Danici je u nastavcima izlazio spis Dimitrija Demetra, tada glavnoga organizatora hrvatskoga kazališnog života. Prva dva dijela spisa nosila su naslov Misli o ilirskom književnom jeziku, a posljednji, treći, Misli o našem književnom jeziku, jer je u međuvremenu zabranjeno ilirsko ime. Najviše je pozornosti u ovome Demetrovu spisu pobudila teza prema kojoj je već dubrovačka književnost iznjedrila uzoran književni jezik i da se pri standardizaciji hrvatskoga književnog jezika treba oslanjati upravo na dubrovačku književnu tradiciju. Podsjećamo, tada se već pripremalo preporodno izdanje Gundulićeva Osmana s Mažuranićevom dopunom, a među hrvatskim preporoditeljima bilo je polemika treba li se više ugledati na Dubrovčane ili na jezik pučke usmene književnosti, za što se 1847. izjasnio Vraz u Kolu. Pored spomenutoga, Demeter je oblikovao i neka opća shvaćanja o standardnome jeziku i njima pokrio njegovu civilizacijsku funkciju, normiranost i višestruku stilsku izgrađenost, na čemu se uglavnom temelji i današnji, suvremeni standardni jezik:

1) Ograničeni mjesni govori nisu dovoljni za razvijeniju komunikaciju šire zajednice.

2) Podloga za zajednički jezik treba biti neko od srodnih narječja, a treba ga obogaćivati iz podnarječja, drugih srodnih narječja, 
posuđenicama iz stranih jezika, a kada je znanost u pitanju - i neologizmima.

3) Izabrano narječje postaje književnim jezikom tek kada je normirano.

4) Književni jezik moraju učiti svi, pa i oni kojima je materinsko ono narječje koje je podloga književnomu jeziku.

5) U književnom se jeziku razlikuju pjesnički jezik i znanstveni jezik. Prvi je slobodan, znanstveni je podvrgnut strogim pravilima.

Iz do sada izloženoga razvidno je da su postojale dvije osnovne tendencije između kojih su se kretali hrvatski preporodni programi 40-ih. Jedni su bili usmjereni više na jezični, književni, općekulturni plan (kakav je bio ovaj Demetrov), a drugi na politička prava Hrvata, prije svega u odnosu na Mađare. I jedni i drugi činili su cjelinu pokreta koji će odrediti budućnost hrvatskoga naroda. Što četrdesete više odmiču, a naročito nakon što su 1945. pale srpanjske žrtve, programi su bliži ovoj drugoj krajnosti, a tako je i s brošurom Ivana Mažuranića Hrvati Mađarom, tiskanom na hrvatskome i mađarskome u travnju 1848., dakle kada su neplemići već dobili određena politička prava, nakon početka revolucije i petnaestak dana nakon donošenja hrvatskih Zahtijevanja naroda. Sadržaj Mažuranićeva spisa jest apsolutno političke naravi, što je sasvim razumljivo u ozračju u kojem cijela srednja Europa zvecka oružjem te nakon isticanja zahtjeva Mađara u ožujku 1848. kojima traže centraliziranu državu s mađarskim kao službenim jezikom, u kojoj bi Slavonija postala sastavnim dijelom Ugarske, a užoj Hrvatskoj ostala bi pokrajinska autonomija itd. Ukratko, Mažuranić ovdje, polazeći od načela Francuske revolucije o slobodi, bratstvu i jednakosti, poziva Mađare, nazivajući ih braćom, da ono što traže za sebe dopuste i ostalim narodima. Ono što već na prvi pogled plijeni pozornost čitatelja jest grafička organizacija ovoga spisa: naime, njegovi paragrafi imaju po jednu, najviše dvije rečenice, pa cijeli tekst neodoljivo podsjeća na pjesmu u prozi i svakako je riječ o spoju poetičkoga ilirizma i političkoga kroatizma, kakvim ih je vidio Vukotinović. 
Nakon poraza političkoga kroatizma u revoluciji 1848. - 1849. brojne $\mathrm{su}$ istaknute javne osobe ilirskoga pokreta svoje interese u neoapsolutizmu koji je uslijedio reaktivirali kao znanstvenici: povjesničari, prirodoslovci, a naročito kao filolozi koji su se često jalovo prepirali oko nevažnih stvari, naročito u sukobima riječke i zagrebačke jezične škole. Imali su Maticu, književni časopis Neven, Društvo za povjesnicu i bogatu tradiciju preporodnog rada na kulturnom polju, zagrebačka je gimnazija pedesetih okupljala profesorsku elitu, no još uvijek su se susretali sa starim problemima. U posljednjem su svesku Kola (1853.) objavljena tri članka u kojima se pokušalo - ako ne udariti temelje, onda barem pripomoći hrvatskoj znanstvenoj terminologiji. Pišući, zapravo prevodeći s češkoga gimnazijski udžbenik iz geografije, Matija Mesić se 1854. u pismu Josefu Jirečeku žalio da mu jednostavno nedostaje hrvatskih riječi (Šabić, 2014: 117-118). Dakle, imao je isti problem kao i Šipuš kada je više od pola stoljeća prije pisao o trgovini žitom. Uvođenje njemačkoga jezika u gimnazije Mesića nije omelo da marljivo radi - u nepunih šest godina do 1858. priredio je čak 7 svezaka školskih knjiga na hrvatskome jeziku, a u svome poslu nije bio usamljen. Sve to pokazuje da kulturni i prosvjetni program iliraca nije odumro s uvođenjem apsolutizma.

Nakon što je Vuk Karadžić u Beču objavio knjigu Kovčežić za istoriju, jezik i običaje Srba sva tri zakona, i u njoj puno prije napisan spis Srbi svi i svuda, pred hrvatskim su se intelektualcima pojavili neki novi izazovi koji su iznjedrili i nove programske tekstove. Jedan od njih je i Starčevićev odgovor na pisanje Srbskog dnevnika da Hrvati trebaju pisati srpskim jezikom, objavljen u Narodnim novinama u kolovozu 1852. Starčević žestoko odgovara da Hrvati ne traže jezik kojim bi pisali, da su ga već davno našli u stotinama knjiga i milijunima duša, da imaju tri narječja i svako je izobraženije nego ono koje neki zovu srpskim, a Hrvat, koji se tuđinstvom pokvario, treba opet naučiti svoj jezik. Svoje je članke o srpstvu i hrvatstvu u Narodnim novinama objavljivao za vrijeme Gajeve odsutnosti, a kada se Gaj vratio u Zagreb, prekinuo je suradnju sa Starčevićem i javno se ogradio od njegova pisanja. Poslije Listopadske diplome većina se hrvatskih intelektualaca posvećuje političkomu radu. Idući će važni programi hrvatskoga romantičnog nacionalizma s političke 
strane doći tek od pravaša i Ante Starčevića, a u književnosti od Augusta Šenoe (članak „Naša književnost“ u Glasonoši), no kada bismo ovo istraživanje proširili i na njih, prešli bismo okvire hrvatskoga književnog romantizma kako ga ograničava većina sinteza povijesti hrvatske književnosti. Nadamo se da smo uspjeli pokazati kako su programi hrvatskoga književnog romantizma prešli put od pretežno kulturno-jezičnih tema u prvim desetljećima 19. stoljeća, preko tvrdo političkih u nesigurnim i ratnim četrdesetima, te kako su se u neoapsolutizmu silom prilika vratili građenju narodne književne i jezične kulture te unaprjeđivanju školstva - drugim riječima, kako su, ovisno o političkim okolnostima, balansirali između tendencija književnoga romantizma i romantičnoga nacionalizma, kako ih je definirao Joep Leerssen.

\section{Literatura}

- BREŠIĆ, VINKO (1994) „Ilirizam - inačica europskog romantizma. Byron i byronizam kao načelo definicije hrvatskoga romantizma", BREŠIĆ, VINKO, Novija hrvatska književnost, Nakladni zavod Matice hrvatske, Zagreb, str. 15-37.

- BREŠIć, VINKo (2014) Hrvatska književnost 19. stoljeća, Alfa, Zagreb.

- Martinčić, Ivan (ur.) (1994) Hrvatski preporod - temeljni programski tekstovi I-II, Erasmus, Zagreb.

- Jakobson, Roman (1987) „Notes on Mith in Erbens Work“, JAKOBSON, RoMAN, Language in Literature, London, str. 379-397.

- Jelčıć, Dubravko (ur.) (2002) Hrvatski književni romantizam, Školska knjiga, Zagreb.

- Jelčıć, Dubravko (2004), Povijest hrvatske književnosti, Naklada Pavičić, Zagreb.

- Ježıć, Slavko (1993) Hrvatska književnost od početka do danas 1100 - 1941., Grafički zavod Hrvatske, Zagreb.

- Leerssen, Joep (2014) When was romantic nationalism? The onset, the long tail, the banal, Antwerp. 
- ŠAbić, MARijAN (2014) „Rad Matije Mesića na školskim knjigama (u svjetlu korespondencije s Josefom Jirečekom i Pavolom Jozefom Šafárikom)“, Croatica christiana periodica, Zagreb, god. XXXVIII, br. 73, str. 113-126.

- ŠICel, Miroslav (1972) Programi i manifesti u hrvatskoj književnosti, Liber, Zagreb.

- ŠICEL, Miroslav (1997) Programski spisi hrvatskog narodnog preporoda, Matica hrvatska, Zagreb.

- Šicel, Miroslav (2004) Povijest hrvatske književnosti XIX. stoljeća. Knjiga I. Od Andrije Kačića Miošića do Augusta Šenoe (17501881), Nalkada Ljevak, Zagreb.

- ŠRePel, Milivoj (1897) „Vrazova pisma“, Grada za povijest književnosti hrvatske, Zagreb, god. I, br. 1, str. 240-249.

- Vodnik, Branko (1993) „Vrazovo “Kolo” (1842.-1843.)“, MartinČIĆ, Ivan (ur.), Knjiga o Kolu, Erasmus, Zagreb, str. 196-205.

- Vukotinović, Ljudevit (1842) „Ilirisam i kroatisam“, Kolo, Zagreb, knj. 2, str. 109-115. 
Review article

Received April 16, 2018

MARIJAN ŠABIĆ

Croatian Institute of History, Department for the History of Slavonia, Srijem and Baranja

\section{THE POLITICAL AND CULTURAL PROGRAMMES OF ROMANTICISM IN CROATIAN LITERATURE (BETWEEN NATIONAL ROMANTICISM AND ROMANTIC NATIONALISM)}

\section{Abstract}

In this article the author gives an overview of the programmes of Croatian literary pre-Romanticism and Romanticism and the National Revival and Illyrian Movement that overlap with them. He also shows how the tendencies of national Romanticism and Romantic nationalism, as defined by Joep Leerssen in European terms, interchanged in the programmatic texts in circumstances defined by Hungarian-Croatian tensions and neo-absolutism.

Keywords: Croatian Romanticism; Croatian literature; Romantic Nationalism; cultural programmes; political programmes 